\title{
Efektivitas Pembelajaran Penemuan Terbimbing Terhadap Hasil Belajar Matematika Siswa Materi Barisan dan Deret
}

\author{
Mohammad Kholil ${ }^{1)}$, Olvi Safianti' ${ }^{2)}$ \\ ${ }^{1,2}$ IAIN Jember \\ Email: muad.kholi1@gmail.com, safiantiolvi27@gmail.com
}

\begin{abstract}
The aim of this research is to determine the effect of discovery learning on outcomes mathematics of students in sequence chapter and series. This research uses a quantitative approach, a type of this research is quasi-experimental with nonequivalent control group desaign. The population of this research was all students of ninth class of Excellent Senior High School BPPT Darus Sholah Jember, the sampling technique was purposive sampling and the sample was class XI A and XI B. The data collection methods used were tests, interviews and observations, and the data analysis used T-test. The result of this research show that the T test of the experimental and control class pre-test obtained $t_{\text {count }}=2.682>t_{\text {table }}=2.052$ means that $H_{0}$ is rejected and $H_{a}$ is accepted. Whereas the results of the T test on the experimental and control class post-test obtained $t_{\text {count }}=2.485>t_{\text {table }}=2.052$ means that $\mathrm{H}_{0}$ is rejected and $H_{a}$ is accepted. Therefore, there is an effect of discovery learning on outcomes mathematics of students in chapter sequence and series.
\end{abstract}

Keywords : discovery learning, learning outcome, sequence and series.

\begin{abstract}
ABSTRAK
Tujuan penelitian ini adalah untuk mengetahui pengaruh pembelajaran penemuan terbimbing terhadap hasil belajar matematika siswa materi barisan dan deret. Penelitian ini menggunakan pendekatan kuantitatif, jenis eksperimen semu dengan desain penelitian nonequivalent control group. Populasi penelitian ini adalah seluruh siswa kelas XI SMA Unggulan BPPT Darus Sholah Jember, teknik samplingnya adalah purposive sampling dan sampelnya siswa kelas XI A dan XI B. Metode pengumpulan datanya menggunakan tes, wawancara dan observasi, dan analisis datanya menggunakan uji $\mathrm{T}$. Hasil penelitian menunjukkan bahwa uji $\mathrm{T}$ terhadap pre-test kelas eksperimen dan kontrol diperoleh $t_{\text {hitung }}=2,682>t_{\text {tabel }}=$ 2,052 artinya $\mathrm{H}_{0}$ ditolak dan $H_{a}$ diterima. Sedangkan hasil uji T terhadap post-test kelas eksperimen dan kontrol diperoleh $t_{\text {hitung }}=2,485>t_{\text {tabel }}=2,052$ artinya $\mathrm{H}_{0}$ ditolak dan $H_{a}$ diterima. Oleh karena itu, terdapat pengaruh pembelajaran penemuan terbimbing terhadap hasil belajar matematika siswa materi barisan dan deret.
\end{abstract}

Kata kunci : pembelajaran penemuan terbimbing, hasil belajar, barisan dan deret. 


\section{PENDAHULUAN}

Matematika merupakan ilmu yang penting dalam kehidupan sehari-hari, khususnya dalam pendidikan. Di sekolah-sekolah mulai dari sekolah dasar hingga perguruan tinggi, bahkan dalam dunia pendidikan prasekolah, misalnya taman kanakkanak, keberadaan matematika selalu diperlukan. Kehadiran matematika dalam dunia pendidikan maupun dalam kehidupan sehari-hari tentu sangat bermanfaat, karena dapat digunakan untuk berhitung, mengolah data, berdagang. Pengguna atau pemakai matematika tentu tidak terbatas, misalnya pelajar, mahasiswa, pedagang, pelaku bisnis dan warga masyarakat lainnya. Para pelajar dan mahasiswa sangat memerlukan matematika dalam rangka memenuhi keperluan studi maupun keperluan sehariharinya.

Matematika secara umum diartikan sebagai ilmu yang mempelajari tentang besaran, struktur, ruang dan perubahan. Para matematikawan mencari berbagai pola, merumuskan dan membangun kebenaran melalui metode deduksi yang kaku dari aksioma-aksioma dan definisi-definisi yang bersesuaian (Muhsetyo, dkk., 2013). Oleh karena itu, diperlukan desain pembelajaran yang tepat untuk mengajarkan matematika kepada siswa. Dalam proses pembelajaran siswa harus memunculkan dorongandorongan untuk menemukan pengalaman yang baru. Proses pembentukan pengetahuan oleh siswa sendiri dinamakan pembelajaran konstruktivis (Kholil, 2015). Menurut Hudojo tujuan pembelajaran berdasarkan pandangan konstruktivis adalah membangun pemahaman. Belajar dalam pandangan ini tidak ditekankan untuk memperoleh pengetahuan yang banyak, tetapi yang lebih utama adalah memberikan informasi melalui skemata yang dimiliki siswa (Kholil, 2015). Oleh karena itu, diperlukan desain pembelajaran matematika yang dapat mendukung siswa untuk membangun pengetahuan dari dalam diri sendiri melalui skemata yang dimiliki siswa sehingga pengetahuan yang dipelajari lebih lama membekas karena siswa dilibatkan dalam proses menemukannya.

Dalam hal ini, Model pembelajaran yang sesuai adalah pembelajaran penemuan terbimbing. Pembelajaran penemuan terbimbing adalah suatu model pembelajaran yang dirancang sedemikian sehingga siswa dapat menemukan konsep- 
konsep dan prinsip-prinsip melalui proses mentalnya sendiri (Zarkasyi, 2017). Dengan alasan inilah, pembelajaran penemuan terbimbing digunakan dalam penelitian.

Pada penelitian ini model pembelajaran penemuan terbimbing digunakan untuk mengajarkan materi barisan dan deret. Materi ini dipelajari oleh peserta didik kelas XI pada semester genap. Salah satu kompetensi dasar dalam materi barisan dan deret yaitu menggeneralisasi pola bilangan dan jumlah pada barisan dan deret aritmetika dan geometri. Dari kompetensi dasar ini, tersirat bahwa untuk menyelesaikan masalah yang berkaitan dengan barisan dan deret, perlu mengolah data yang telah dikumpulkan. Proses pengumpulan dan pengolahan data itu sesuai dengan sintaks pada model pembelajaran penemuan terbimbing, yaitu tahapan data collecting dan data processing. Oleh karena itu, materi barisan dan deret dan deret sangat tepat diajarkan karena sesuai dengan sintaks atau langkah-langkah dalam model pembelajaran penemuan terbimbing.

Berdasarkan hasil observasi pendahuluan yang dilakukan di kelas XI SMA Unggulan BPPT Darus Sholah Jember diperoleh bahwa kelas XI sudah menggunakan kurikulum 2013, namun pada prakteknya masih sering menggunakan kurikulum KTSP. Guru tidak menggunakan pendekatan scientific yang terdiri dari 5M yaitu menanya, mengamati, menalar, mengasosiasikan dan mengkomunikasikan. Namun, guru menggunakan model pembelajaran konvensional dengan metode ekspositori. Metode ekspositori merupakan suatu proses pembelajaran yang berorientasi kepada guru, guru memegang peranan yang sangat dominan (Heruman, 2009). Dalam model pembelajaran ini, guru cenderung memegang kendali proses pembelajaran secara aktif, sementara siswa hanya menerima dan mengikuti apa yang disajikan oleh guru. Berdasarkan latar belakang tersebut di atas, penelitian ini dilaksanakan dengan judul "Efektivitas Pembelajaran penemuan terbimbing Terhadap Hasil Belajar Matematika Siswa Materi Barisan dan Deret" di kelas XI SMA Unggulan BPPT Darus Sholah Jember semester genap tahun pelajaran 2018/2019.

\section{METODE PENELITIAN}

Penelitian ini menggunakan pendekatan penelitian kuantitatif. Hal ini karena dalam penelitian ini menggunakan data numerik yang dapat diolah dengan menggunakan statistic (Winarsunu, 2017). Pendekatan kuantitatif adalah suatu 
pendekatan penelitian yang secara primer menggunakan paradigma postpositivist dalam mengembangkan ilmu pengetahuan, menggunakan strategi penelitian seperti eksperimen dan survei yang memerlukan data statistik (Zarkasyi, 2017).

Sedangkan jenis penelitian yang digunakan dalam penelitian ini adalah penelitian eksperimen. Penelitian eksperimen dapat diartikan sebagai penelitian yang digunakan untuk mencari pengaruh perlakuan tertentu terhadap yang lain dalam kondisi yang terkendalikan (Sugiyono, 2017). Desain eksperimen dalam penelitian ini menggunakan desain eksperimen semu (quasi experimental) dimana peneliti memberikan perlakuan pada subjek. Prosedur eksperimen semu ini dilakukan dengan mengacu pada jenis nonequivalent control group design (Sugiyono, 2017). Rancangan ini digunakan karena (Creswell, 2012): 1) obyek penelitian yaitu kelompok eksperimen dan kelompok kontrol tidak dipilih secara random, 2) variabel-variabel lain selain variabel bebas yang berpengaruh terhadap variabel terikat dalam penelitian tidak dapat dikontrol sepenuhnya seperti eksperimen sebenarnya. Desain penelitian yang digunakan dalam penelitian ini sebagai berikut:

Tabel 1. Nonequivalent Control Group Design

\begin{tabular}{|c|c|c|}
\hline $\mathrm{O}_{1}$ & $\mathrm{X}$ & $\mathrm{O}_{2}$ \\
\hline $\mathrm{O}_{3}$ & & $\mathrm{O}_{4}$ \\
\hline
\end{tabular}

Sumber: Sugiyono (2017)

Obyek penelitian ini ada dua yaitu kelompok eksperimen dan kelompok kontrol yang tidak dipilih secara random. Kelompok eksperimen diberi perlakuan menggunakan model pembelajaran penemuan terbimbing, sedangkan kelompok kontrol tidak diberi perlakuan. $\mathrm{O}_{1}$ dan $\mathrm{O}_{3}$ merupakan tes awal (pre-test) sebelum diberi perlakuan model pembelajaran penemuan terbimbing. $\mathrm{O}_{2}$ merupakan tes akhir (post-test) setelah diberi perlakuan model pembelajaran penemuan terbimbing. $\mathrm{O}_{4}$ merupakan tes akhir (post-test) yang tidak diberi perlakuan model pembelajaran penemuan terbimbing.

Dalam penelitian ini, populasi yang ditetapkan oleh peneliti yaitu seluruh kelas XI di SMA Unggulan BPPT Darus Sholah Jember yaitu kelas XI A, XI B, XI C dan XI D sebanyak 97 siswa. Peneliti mengambil kelas XI dikarenakan sesuai dengan materi yang diajarkan yaitu barisan dan deret. Teknik pengambilan sampel dalam penelitian ini, peneliti menggunakan purposive sampling (Sugiyono, 2015). Kelas 
yang terpilih sebagai kelas eksperimen sebanyak 29 siswa yang berasal dari kelas XI A dengan menggunakan model pembelajaran pembelajaran penemuan terbimbing, sedangkan kelas yang terpilih sebagai kelas kontrol sebanyak 28 siswa adalah kelas XI B.

Teknik pengumpulan data dalam penelitian ini menggunakan tes, wawancara dan observasi (Sugiyono, 2017) yang dituangkan dalam soal tes, pedoman wawancara dan lembar observasi. Instrumen tersebut kemudian divalidasi dengan teknik uji validitas dan reliabilitas. Analisis data dalam penelitian ini menggunakan bantuan software IBM SPSS Statitics 20 yang terdiri dari uji normalitas dan uji homogenitas (Kholil, 2018) sebagai uji prasyarat, kemudian dilanjutkan dengan melakukan uji T (Sugiyono, 2015) untuk melihat pengaruh dari pembelajaran penemuan terbimbing terhadap hasil belajar matematika siswa materi barisan dan deret.

Kriteria uji normalitas dengan cara membandingkan taraf signifikansi $\alpha=$ 0,05 dengan signifikansi yang diperoleh melalui SPSS. Jika signifikansi yang diperoleh $\geq \alpha$, maka sampel berasal dari populasi yang berdistribusi normal. Jika signifikansi yang diperoleh $<\alpha$, maka sampel bukan berasal dari populasi yang berdistribusi normal (Kholil, 2018). Sedangkan untuk uji homogenitas menggunakan uji levene dengan cara melihat nilai dari Levene Statistic, jika nilai Levene Statistic > 0,05 maka dapat dikatakan bahwa variasi data adalah homogen (Nuryadi, Dkk, 2017).

Uji T dilakukan dengan cara membandingkan hasil output SPSS (thitung) dengan $t_{\text {tabel }}$ dimana taraf signifikansi $\alpha=0,05$ dan derajat bebas $d f=N-1$ (Sugiyono, 2015). Jika $t_{\text {hitung }}>t_{\text {tabel }}$, maka $H_{0}$ ditolak dan $H_{a}$ diterima, yang artinya terdapat perbedaan antara kelas eksperimen dan kelas kontrol. Sebaliknya jika $t_{\text {hitung }} \leq t_{\text {tabel }}$, maka $H_{0}$ diterima dan $H_{a}$ ditolak, artinya tidak terdapat perbedaan antara kelas eksperimen dan kelas kontrol.

\section{HASIL DAN PEMBAHASAN}

Hasil belajar matematika siswa sebelum diajarkan menggunakan model pembelajaran penemuan terbimbing sebagai berikut: a) siswa yang mendapatkan nilai 14 sebanyak dua siswa; b) siswa yang mendapatkan nilai 22 sebanyak dua siswa; c) siswa yang mendapatkan nilai 24 sebanyak dua siswa; d) siswa yang mendapatkan 
nilai 26 sebanyak satu siswa; e) siswa yang mendapatkan nilai 28 sebanyak empat siswa; f) siswa yang mendapatkan nilai 30 sebanyak empat siswa; g) siswa yang mendapatkan nilai 32 sebanyak empat siswa; h) siswa yang mendapatkan nilai 34 sebanyak tiga siswa; i) siswa yang mendapatkan nilai 36 sebanyak tiga siswa; j) siswa yang mendapatkan nilai 38 sebanyak tiga siswa; dan k) siswa yang mendapatkan nilai 40 sebanyak satu siswa.

Dari hasil tersebut diketahui nilai maksimum dari hasil belajar matematika siswa sebelum diajarkan menggunakan model pembelajaran penemuan terbimbing sebesar 40, sedangkan nilai minimumnya sebesar 14. Berdasarkan perhitungan diperoleh nilai simpangan baku (standar deviasi) sebesar 6,568. Rata-rata hasil belajar matematika siswa sebelum diajarkan menggunakan model pembelajaran penemuan terbimbing adalah 30. Nilai rata-rata tersebut berada dibawah nilai KKM yaitu dibawah nilai 75 .

Hasil belajar matematika siswa setelah diajarkan menggunakan model pembelajaran penemuan terbimbing sebagai berikut: a) siswa yang mendapatkan nilai 58 sebanyak satu siswa; b) siswa yang mendapatkan nilai 62 sebanyak satu siswa; c) siswa yang mendapatkan nilai 64 sebanyak dua siswa; d) siswa yang mendapatkan nilai 68 sebanyak dua siswa; e) siswa yang mendapatkan nilai 70 sebanyak tiga siswa; f) siswa yang mendapatkan nilai 72 sebanyak tiga siswa; g) siswa yang mendapatkan nilai 76 sebanyak lima siswa; h) siswa yang mendapatkan nilai 78 sebanyak satu siswa; i) siswa yang mendapatkan nilai 80 sebanyak lima siswa; j) siswa yang mendapatkan nilai 84 sebanyak tiga siswa; k) siswa yang mendapatkan nilai 86 sebanyak dua siswa; dan 1) siswa yang mendapatkan nilai 88 sebanyak satu siswa.

Dari hasil tersebut diketahui nilai maksimum dari hasil belajar matematika siswa setelah diajarkan menggunakan model pembelajaran penemuan terbimbing sebesar 88, sedangkan nilai minimumnya sebesar 58. Berdasarkan perhitungan diperoleh nilai simpangan baku (standar deviasi) sebesar 7,774. Rata-rata hasil belajar matematika siswa setelah diajarkan menggunakan model pembelajaran penemuan terbimbing adalah 75,17. Nilai rata-rata tersebut berada di atas nilai KKM yaitu diatas nilai 75. Dengan demikian, hasil belajar yang dicapai siswa lebih maksimal setelah menggunakan model pembelajaran penemuan terbimbing. 
Rata-rata hasil belajar matematika siswa sebelum diajarkan menggunakan model pembelajaran penemuan terbimbing sebesar 30. Sedangkan rata-rata hasil belajar matematika siswa setelah diajarkan menggunakan model pembelajaran pembelajaran penemuan terbimbing sebesar 75,17 . Nilai rata-rata post-test tersebut berada diatas nilai KKM. Dengan demikian, hasil belajar yang dicapai siswa lebih maksimal.

Hasil dari pre-test kelas eksperimen dan pre-test kelas kontrol serta post-test kelas eksperimen dan post-test kelas kontrol selanjutnya dilakukan uji normalitas dan uji homogenitas. Dari uji normalitas dan uji homogenitas menunjukkan bahwa data pre-test dan post-test kelas eksperimen serta data pre-test dan post-test kelas kontrol berdistribusi normal dan homogen. Setelah data dinyatakan berdistribusi normal dan homogen maka kedua syarat terpenuhi untuk melakukan uji selanjutnya.

Selanjutnya menguji hipotesis dengan menggunakan uji T. Hasil uji T pretest dan post-test kelas eksperimen dan kontrol dengan menggunakan SPSS dapat dilihat pada Tabel 2 dan Tabel 3 berikut.

Tabel 2. Uji T Pre-Test Kelas Eksperimen dan Kelas Kontrol

\begin{tabular}{|c|c|c|c|c|c|c|c|c|c|}
\hline & \multicolumn{5}{|c|}{ Paired Differences } & \multirow[b]{3}{*}{$\mathrm{T}$} & \multirow[b]{3}{*}{ Df } & \multirow{3}{*}{$\begin{array}{l}\text { Sig. (2- } \\
\text { tailed) }\end{array}$} \\
\hline & & \multirow[b]{2}{*}{ Mean } & \multirow{2}{*}{$\begin{array}{c}\text { Std. } \\
\text { Deviation }\end{array}$} & \multirow{2}{*}{$\begin{array}{l}\text { Std. } \\
\text { Error } \\
\text { Mean }\end{array}$} & \multicolumn{2}{|c|}{$\begin{array}{l}95 \% \text { Confidence } \\
\text { Interval of the } \\
\text { Difference }\end{array}$} & & & \\
\hline & & & & & Lower & Upper & & & \\
\hline $\begin{array}{l}\text { Pair } \\
1\end{array}$ & $\begin{array}{l}\text { Pre Test } \\
\text { Eksperimen - } \\
\text { Pre Test } \\
\text { Kontrol }\end{array}$ & 7.143 & 14.094 & 2.664 & 1.678 & 12.608 & 2.682 & 27 & .012 \\
\hline
\end{tabular}

Tabel 3. Uji T Post-Test Kelas Eksperimen dan Kelas Kontrol

\begin{tabular}{|c|c|c|c|c|c|c|c|c|}
\hline & \multicolumn{5}{|c|}{ Paired Differences } & \multirow[b]{3}{*}{$\mathrm{T}$} & \multirow[b]{3}{*}{ Df } & \multirow{3}{*}{$\begin{array}{l}\text { Sig. (2- } \\
\text { tailed) }\end{array}$} \\
\hline & \multirow[b]{2}{*}{ Mean } & \multirow{2}{*}{$\begin{array}{c}\text { Std. } \\
\text { Deviation }\end{array}$} & \multirow{2}{*}{$\begin{array}{c}\text { Std. Error } \\
\text { Mean }\end{array}$} & \multicolumn{2}{|c|}{$\begin{array}{l}95 \% \text { Confidence } \\
\text { Interval of the } \\
\text { Difference } \\
\end{array}$} & & & \\
\hline & & & & Lower & Upper & & & \\
\hline $\begin{array}{ll}\text { Pair } 1 & \text { Post Test } \\
& \text { Eksperimen - } \\
& \text { Post Test } \\
& \text { Kontrol }\end{array}$ & 5.714 & 12.168 & 2.300 & .996 & 10.433 & 2.485 & 27 & .019 \\
\hline
\end{tabular}

Berdasarkan Tabel 2 diperoleh $t_{\text {hitung }}$ sebesar 2,682. Selanjutnya $t_{\text {hitung }}$ dibandingkan dengan $t_{\text {tabel }}$ dengan degree of freedom $(\mathrm{df})$ yaitu $\mathrm{df}=\mathrm{N}-1=28-1=$ 27. Dengan df $=27$ dan taraf kesalahan ditetapkan sebesar $5 \%$, maka $t_{\text {tabel }}$ sebesar 
2,052. Hasil ini berakibat $t_{\text {hitung }}>t_{\text {tabel }}$ yaitu 2,682 $>2,052$, hal ini dapat disimpulkan bahwa $H_{0}$ ditolak dan $H_{a}$ diterima. Maka dapat ditarik kesimpulan bahwa ada perbedaan hasil belajar pre-test siswa antara kelas eksperimen dengan kelas kontrol.

Berdasarkan Tabel 3 diperoleh $t_{\text {hitung }}$ sebesar 2,485. Selanjutnya $t_{\text {hitung }}$ dibandingkan dengan $t_{\text {tabel }}$ dengan degree of freedom (df) yaitu df $=\mathrm{N}-1=28-1=$ 27. Dengan df $=27$ dan taraf kesalahan ditetapkan sebesar $5 \%$, maka $t_{\text {tabel }}$ sebesar 2,052 . Hasil ini berakibat $t_{\text {hitung }}>t_{\text {tabel }}$ yaitu 2,485 $>2,052$, hal ini dapat disimpulkan bahwa $H_{0}$ ditolak dan $H_{a}$ diterima. Maka dapat ditarik kesimpulan bahwa ada perbedaan hasil belajar post-test siswa kelas eksperimen dengan kelas kontrol.

Dari hasil tersebut diperoleh bahwa ada perbedaan hasil belajar pre-test dan post-test kelas eksperimen dan kelas kontrol. Hal ini menunjukkan bahwa terdapat pengaruh model pembelajaran penemuan terbimbing terhadap hasil belajar matematika siswa pada materi barisan dan deret kelas XI SMA Unggulan BPPT Darus Sholah Jember.

Hasil penelitian ini didukung oleh pendapatnya Wilcolk yang mengemukakan bahwa dalam pembelajaran penemuan, siswa didorong untuk belajar aktif melalui keterlibatan aktif mereka sendiri dengan konsep-konsep, prinsip-prinsip dan guru mendorong siswa untuk memiliki pengalaman dan melakukan percobaan yang memungkinkan mereka menemukan prinsip-prinsip untuk diri mereka sendiri (Suprihatin, 2013). Keterlibatan siswa saat belajar dengan cara menerapkan model pembelajaran penemuan terbimbing merupakan salah satu indikator keefektifan belajar. Siswa tidak hanya menerima saja materi dari guru melainkan siswa juga aktif dalam menggali dan menemukan sendiri. Sehingga hasil belajar yang dicapai siswa akan lebih maksimal.

Selain itu, hasil penelitian ini juga didukung oleh pendapat Bruner yang mengemukakan bahwa melalui penemuan terbimbing, siswa yang lambat belajar akan mengetahui bagaimana menyusun dan melakukan penyelidikan. Salah satu keuntungan pembelajaran dengan menggunakan pendekatan penemuan terbimbing adalah materi yang dipelajari lebih lama membekas karena siswa dilibatkan dalam proses menemukannya (Suprihatin, 2013). Hal inilah yang menjadi salah satu yang menyebabkan penggunaan model pembelajaran penemuan terbimbing dapat meningkatkan hasil belajar siswa. Dengan demikian, hasil penelitian yang dilakukan 
peneliti dapat disimpulkan bahwa penggunaan model pembelajaran penemuan terbimbing dapat meningkatkan hasil belajar siswa.

\section{KESIMPULAN DAN SARAN}

Berdasarkan hasil penelitian yang dilaksanakan mengenai pembelajaran matematika dengan menerapkan model pembelajaran penemuan terbimbing terhadap hasil belajar matematika siswa kelas XI SMA Unggulan BPPT Darus Sholah Jember diperoleh kesimpulan bahwa bedasarkan hasil uji $\mathrm{T}$ terhadap data pre-test kelas eksperimen dan kelas kontrol diperoleh $t_{\text {hitung }}>t_{\text {tabel }}$ yaitu 2,682 $>2,052$ artinya $H_{0}$ ditolak dan $H_{a}$ diterima, maka terdapat perbedaan hasil belajar pre-test siswa antara kelas eksperimen dan kelas kontrol. Sedangkan hasil uji T terhadap data post-test kelas eksperimen dan kelas kontrol diperoleh $t_{\text {hitung }}>t_{\text {tabel }}$ yaitu 2,485 $>2,052$ artinya $H_{0}$ ditolak dan $H_{a}$ diterima, maka terdapat perbedaan hasil belajar post-test siswa antara kelas eksperimen dan kelas kontrol. Sehingga dapat disimpulkan bahwa terdapat perbedaan antara hasil belajar matematika siswa yang diajarkan menggunakan model pembelajaran penemuan terbimbing dengan model pembelajaran konvensional pada materi barisan dan deret kelas XI SMA Unggulan BPPT Darus Sholah Jember. Dengan adanya perbedaan tersebut, berarti terdapat pengaruh model pembelajaran penemuan terbimbing terhadap hasil belajar matematika siswa pada materi barisan dan deret kelas XI SMA Unggulan BPPT Darus Sholah Jember.

\section{REFERENSI}

Creswell, J. W. (2012). Educational research: planning, conducting, and evaluating quantitative and qualitative research - 4th ed. Boston: Pearson Education, Inc.

Heruman. (2009). Model Pembelajaran Matematika di Sekolah. Bandung: PT Remaja Rosdakarya.

Kholil, M. (2015). PEMBELAJARAN DENGAN PENDEKATAN OPEN-ENDED UNTUK MENINGKATKAN KEMAMPUAN BERPIKIR KREATIF. FENOMENA, 14(2).

Kholil, M.-. (2018). Buku Ajar: Statistika Pendidikan dengan Bantuan SPSS. Jember: FTIK IAIN Jember. 
Muhsetyo, G., dkk. (2013). Pembelajaran Matematika SD. Tangerang Selatan: Universitas Terbuka.

Nuryadi, dkk. (2017). Dasar-Dasar Statistik Pendidikan. Jogjakarta: Sibuku Media.

Sugiyono. (2015). Statistika untuk Penelitian. Bandung: Alfabeta.

Sugiyono. (2017). Metode Penelitian Pendidikan (Pendekatan Kuantitatif, Kualitatif, dan $R \& D)$. Bandung: Alfabeta.

Suprihatin, J. (2013). Strategi Pembelajaran Teori \& Aplikasi. Jogjakarta: Ar-Ruzz Media Grup.

Winarsunu, T. (2017). Statistik dalam penelitian Psikologi dan Pendidikan. Malang: UMM Press.

Zarkasyi, W. (2017). Penelitian Pendidikan Matematika. Bandung: PT Refika Aditama. 